\title{
A comparative study of the effect of two-stage olive cake added to alfalfa on digestion and nitrogen losses in sheep and goats
}

\author{
D. R. Yáñez-Ruiz ${ }^{1 \dagger}$ and E. Molina-Alcaide ${ }^{2}$ \\ ${ }^{1}$ Institute of Rural Sciences, University of Wales, Llanbadarn Campus, Aberystwyth SY23 3AL, UK; ${ }^{2}$ Unidad de Nutrición Animal, \\ Estación Experimental del Zaidin (CSIC), Camino del Jueves s/n, 18100 Armilla, Granada, Spain
}

(Received 11 May 2006; Accepted 13 October 2006)

\begin{abstract}
This work was conducted to evaluate the effect of tannins, contained in a by-product derived from olive oil extraction (two-stage olive cake), on nutrient digestibility, nitrogen ( $N$ ) losses and liver and kidney functions in goats and wethers. Six Segureña wethers and six Granadina goats were fed three experimental diets: alfalfa hay (AH); alfalfa hay and a concentrate (formulated with twostage olive cake, barley and a mineral-vitamin mixture) without (AHCO) or with polyethylene glycol (PEG) addition (AHCOP). The inclusion of two-stage olive cake increased condensed tannins content of the diet and led to a decrease $(\mathrm{P}<0.001)$ in dry matter, organic matter, neutral-detergent fibre, acid-detergent fibre and crude protein (CP) digestibility. PEG supply increased $(\mathrm{P}<0.001) \mathrm{CP}$ digestibility and $N$ losses in urine and faeces only in wethers. Concentrations of creatinine and alkaline phosphatase activity, measured in the serum of animals, were not modified either by olive cake inclusion or by PEG supply. Results from this work indicate a higher sensitivity of sheep to diets containing condensed tannins, compared with goats, and reveal no toxic effect of tannins from two-stage olive cake at the concentration used in the experimental diets.
\end{abstract}

Keywords: goats, olive cake, polyethylene glycol, sheep, tannins.

\section{Introduction}

By-products obtained from the olive oil industry (essentially, olive cake and olive leaves) offer an alternative source of nutrients for ruminant livestock in the Mediterranean areas, where $90 \%$ of the world olive oil production takes place. Olive cake is obtained in high quantities (Alburquerque et al., 2004) and its use, in practical ruminant feeding, has been widely reported, either fresh, dry or ensiled. However, a new centrifugation system for olive oil extraction (twostage system) has been adopted over the last 10 years in Spain, Italy and Greece. In this system, in comparison with the traditional three-stage procedure, two main products are obtained after centrifugation of the olives: olive oil and a wet by-product, two-stage olive cake (TSOC). The TSOC includes water extract and, as a consequence, polyphenols with potential antinutritional activity, such as condensed tannins (CT). A better understanding of the comparative digestive capacity between sheep and goats in using TSOC is essential in order accurately to formulate diets including this by-product. Comparative research on sheep and goat digestive capacity is scarce, especially on the use of

\footnotetext{
${ }^{\dagger}$ E-mail: dyy@aber.ac.uk
}

tannin-containing foods (Núñez-Hernandez et al., 1991). Landau et al. (2000) reported that goats utilise CT-rich foods better than do sheep. In a previous work (Yáñez Ruiz et al., 2004) we also pointed out that microbial protein synthesis was only significantly increased by polyethylene glycol (PEG) treatment, a tannins-binding compound, in sheep fed diets containing TSOC, in comparison with goats. However, the comparative interspecies effect of PEG on total tract digestion, nitrogen $(\mathrm{N})$ losses and, the possible systemic toxic effect of CT have not been assessed yet. This information would help to understand the different response observed in sheep and goats when fed CT-rich foods.

On the other hand, the toxic effect of $\mathrm{CT}$, reflected by damage in the liver, kidneys and the epithelium of the digestive tract (Kumar and Singh, 1984; Reed, 1995; Hervás et al., 2003) has been considered as one of the most important factors in explaining the deleterious influence of tannins on nutrient digestibility (Bryant et al., 1991) although this effect varies depending on type and concentration of CT.

The objective of this work was to study comparatively, in goats and sheep, the nutritive utilisation of practical diets including two-stage olive cake in the whole digestive tract. The effects of $\mathrm{CT}$, present in the by-product, on 
nutritive utilisation of diets and on liver and kidney functions were also studied.

\section{Material and methods}

Animals and experimental diets

Six adult dry non-pregnant Granadina goats $(45 \pm 2.8 \mathrm{~kg}$ live weight) and six Segureña wethers $(71 \pm 3.4 \mathrm{~kg}$ live weight) were used. Three experimental diets were formulated: alfalfa hay $(\mathrm{AH}), \mathrm{AH}$ and pellets $(\mathrm{CO})$ containing rolled barley and TSOC without (AHCO) or with (AHCOP) PEG. This paper reports further results from an experiment previously published (Yáñez Ruiz et al., 2004) on rumen fermentation, in sacco degradability and microbial protein synthesis. Diets were provided in two equal meals at 0900 and $1600 \mathrm{~h}$. Ingredients and chemical composition of experimental diets are shown in Table 1.

Animals were housed in individual metabolism crates and had free access to fresh water. The experimental design consisted of a Latin Square with two animals of each species allocated randomly at the start of the experiment to one of the three experimental diets. Each period consisted of 20-day adaptation, 7 days of total faecal

Table 1 Ingredients and chemical composition of the experimental $\operatorname{diets}^{\dagger}$

\begin{tabular}{lccc}
\hline \hline Experimental diet & AH & AHCO & AHCOP \\
\hline Ingredients (g/kg DM) & & & \\
$\quad$ Alfalfa hay & 973 & 568 & 557 \\
Two-stage olive cake ${ }^{\ddagger}$ & & 128 & 122 \\
Barley grain & & 277 & 272 \\
Polyethylene glycol & & & 21.9 \\
Mineral-vitamin mixture & 25.0 & 27.4 & 27.3 \\
Chemical composition (g/kg DM) & & & \\
Dry matter & 918 & 913 & 913 \\
Organic matter & 882 & 905 & 905 \\
Nitrogen & 30.0 & 25.4 & 25.4 \\
Ether extract & 17.0 & 24.0 & 24.0 \\
Neutral-detergent fibre & 419 & 401 & 401 \\
Acid-detergent fibre & 216 & 191 & 191 \\
Acid-detergent lignin & 54.5 & 58.5 & 58.5 \\
ADIN (g/100 g total N) & 62.0 & 107 & 107 \\
Gross energy (MJ/kg DM) & 180 & 181 & 181 \\
Condensed tannins (CT) (g/kg DM) & & & \\
Free CT & 0.82 & 4.96 & 4.96 \\
Protein-bound CT & 1.70 & 6.92 & 6.92 \\
Fibre-bound CT & 0.25 & 4.84 & 4.84 \\
Total CT & 2.77 & 16.7 & 16.7 \\
\hline \hline
\end{tabular}

${ }^{\dagger} \mathrm{AH}=$ alfalfa hay, $\mathrm{AHCO}=$ alfalfa hay and pellets (TSOC plus barley plus mineral-vitamin mixture), and AHCOP $=$ AHCO plus polyethylene glycol (PEG). Mineral-vitamin mixture was formulated with $300 \mathrm{~g}$ sodium chloride and $700 \mathrm{~g}$ commercial vitamin-mineral (Ovifort, NANTA, SA) with the composition (per kg): Ca $0.155 \mathrm{mg}, P 0.097 \mathrm{mg}, \mathrm{Mg} 0.097 \mathrm{mg}$, Se $0.006 \mu \mathrm{g}$, Co $0.014 \mu \mathrm{g}$, Fe $0.0027 \mathrm{mg}$, Zn $0.0039 \mathrm{mg}, \mathrm{Mn} 0.003 \mathrm{mg}$, S $0.028 \mathrm{mg}$, retinal $120 \mathrm{mg}$, cholecalciferol $2 \mathrm{mg}$ and $\alpha$-tocopherol $150 \mathrm{mg}$.

${ }^{\ddagger}$ Chemical composition ( $\mathrm{g} / \mathrm{kg}$ dry matter): dry matter 876 , organic matter 889 , nitrogen 15.8, ether extract 2.5, neutral-detergent fibre 632, acid-detergent fibre 430, acid-detergent lignin 236, 473 total CT. and urine collection and 3 days of blood sampling. The experiment was carried out by following the established guidelines of the Spanish Research Council (approval no. 123/03) concerning the use of animals in research, which are in compliance with European Directive 86/609.

\section{Liver and kidney function}

Blood samples $(10 \mathrm{ml})$ were collected from the jugular vein of each animal for serum profile studies before the morning feeding, on three consecutive days. Blood was kept at $4^{\circ} \mathrm{C}$ for $4 \mathrm{~h}$, and then serum collected, transferred to a $5 \mathrm{ml}$ tube and centrifuged at $500 \mathrm{~g}$ for $10 \mathrm{~min}$. Supernatant was transferred to eppendorf tubes and kept at $-20^{\circ} \mathrm{C}$ for analysis. Samples were assayed for alkaline phosphatase activity (ALP, IU/l) and creatinine content (mg/dl). The activity of ALP and creatinine concentration in blood have been used to examine the potential toxic effect of tannincontaining foods in ruminants and have been shown to reflect damage in the liver and kidneys, respectively (Silanikove et al., 1996).

In vivo digestibility and $\mathrm{N}$ losses

Total faeces and urine production and feed refusals were collected for 7 days from each animal, then weighed and aliquots representing 10, 20 and $30 \%$ of daily collection, respectively, were stored at $-20^{\circ} \mathrm{C}$ for chemical analyses. Urine was collected in buckets containing $10 \%$ (vol/vol) sulphuric acid to keep final pH below 3 and avoid N losses. Samples of food offered were also collected daily, pooled and stored at $-20^{\circ} \mathrm{C}$.

\section{Laboratory analyses}

Samples of offered and refused food and of faeces were dried at $60^{\circ} \mathrm{C}$ for $48 \mathrm{~h}$, then mill-ground (1-mm screen) and analysed for dry matter (DM), organic matter (OM), ether extract (EE) and $\mathrm{N}$, according to the Association of Official Analytical Chemists (1984) methods. The gross energy (GE) content was determined in an adiabatic calorimeter. The neutral- and acid-detergent fibre (NDF and ADF) and aciddetergent lignin (ADL) analyses were performed by the sequential procedure of Van Soest and Masson (1991) by using the Ankom 200/220 fibre analyser (Ankom, 2000). The NDF was assayed with sodium sulphite and without $\alpha$-amylase, and both NDF and ADF were expressed without residual ash.

Free, protein and fibre bound CTs were determined in feed samples using the procedure proposed by Pérez Maldonado and Norton (1996). CTs from quebracho powder (Roy Wilson Dickson Ltd, Mold, UK) were used as standard.

The ALP activity was determined by measuring the increase in the absorbance $(405 \mathrm{~nm})$ due to the formation of p-nitrophenol from p-nitrophenolphiosphate esther (Inquebor, SA, Granada, Spain). The creatinine content in serum was measured as the absorbance $(492 \mathrm{~nm})$ after incubation of samples with picric acid and using external standard (Inquebor, SA Granada, Spain). 
Statistical analysis

Experimental data were subjected to analysis of variance using the mixed linear model procedure of Statistical Analysis Systems Institute (SAS, 1985) with a model that included the random effect of the animal and fixed effects of animal species, diet and the interaction. If a value of $P<0.05$ appeared, differences among means and variable interactions were tested with Bonferroni $t$ test.

\section{Results}

Feed composition and daily intakes

Chemical composition of diets formulated with $\mathrm{AH}$ plus TSOC was not very different from that of $\mathrm{AH}$, although a reduction of $\mathrm{N}$ and an increase of total CT were observed (Table 1).

The average DM offered and consumed ( $\mathrm{g}$ ) by goats were 918 and $829 \pm 42.5$ (AH diet), 835 and $810 \pm 51.4$ (AHCO diet) and 861 and $831 \pm 45.6$ (AHCOP diet). Corresponding amounts for wethers were 1377 and $1319 \pm 39.1$ (AH diet), 1250 and $1250 \pm 35.1$ (AHCO diet) and 1305 and $1276 \pm 34.2$ (AHCOP diet).

\section{Nutrient apparent digestibility}

The inclusion of TSOC (AHCO and AHCOP diets) reduced nutrient digestibility compared with $\mathrm{AH}$ diet in goats and wethers (Table 2), especially for NDF and ADF. A comparison between AHCO and AHCOP diets revealed only differences in NDF and ADF digestibility: values corresponding to animals fed diet AHCOP were higher $(P<0.001)$ than those in animals fed AHCO diet, independently of the animal species. A significant interaction between animal species and diet was observed for DM, OM and CP digestibility, which evidences the different response of wethers and goats to PEG treatment.

\section{$N$ losses}

In goats, $\mathrm{N}$ intake was not different $(P>0.05)$ across diets (Table 3). However, wethers consumed significantly less $N$ when TSOC was included in the diet. In both animal species faecal $\mathrm{N}$ excretion was increased when they were fed AHCO diet in comparison with $\mathrm{AH}$ and, decreased $(P<0.05)$ as a consequence of PEG treatment. Urinary $\mathrm{N}$ excretion was also higher $(P<0.05)$ in goats and wethers fed diet AHCO compared with $\mathrm{AH}$ and, unaffected by PEG treatment

Liver and kidney function

The serum creatinine concentration was similar in goats and wethers fed the different experimental diets (Table 4). The PEG supply did not $(P>0.01)$ modify the serum creatinine concentration in any of the animal species. The activity of ALP was increased $(P<0.05)$ in wethers fed diets $\mathrm{AHCO}$ and AHCOP in comparison with $\mathrm{AH}$ diet.

\section{Discussion}

Information about TSOC chemical composition is scarce although, in general, it is similar to that of olive cake obtained from the previously used three-stage extraction technology (Molina Alcaide et al., 2003). However, the twostage olive cake includes water extract, which were obtained separately in the three-stage technology, being rich in polyphenols (Ramos Cormenzana et al., 1996). As a consequence, higher tannins content could be expected in TSOC in comparison with three-stage olive cake. In fact, we found $43.4 \mathrm{~g} / \mathrm{kg}$ DM of CTs in TSOC and Nefzaoui (1985) found $13.6 \mathrm{~g} / \mathrm{kg} \mathrm{DM}$ in the three-stage olive cake.

\section{Nutrient apparent digestibility}

The beneficial effect of PEG supply on NDF and ADF digestibility may reflect a deleterious effect of CT contained in TSOC on the digestibility of structural carbohydrates, in agreement with other observations (Ben Salem et al., 1999). The accuracy of the conventional detergent extraction techniques for fibrous components analysis has been criticised in the case of tannin rich forages (Reed, 1986) by a confounding in the analysis, so the results reported here should be interpreted with caution. Nevertheless, others have used this technique and found deleterious effects of CT on NDF (Priolo et al., 2000) and ADF (Ben Salem et al., 2000) digestibility in sheep fed, respectively, carob pulp and Acacia cyanophylla.

Table 2 Effect of the experimental diets and animal species the apparent nutrient digestibility coefficients in wethers and goats

\begin{tabular}{|c|c|c|c|c|c|c|c|c|c|c|}
\hline \multirow[b]{3}{*}{ Experimental diets ${ }^{\dagger}$} & \multicolumn{6}{|c|}{ Animal species } & \multirow[b]{3}{*}{ s.e.d. } & \multirow{2}{*}{\multicolumn{3}{|c|}{ Significance $^{\ddagger}$}} \\
\hline & \multicolumn{3}{|c|}{ Goats } & \multicolumn{3}{|c|}{ Wethers } & & & & \\
\hline & $\mathrm{AH}$ & $\mathrm{AHCO}$ & AHCOP & $\mathrm{AH}$ & $\mathrm{AHCO}$ & AHCOP & & AS & $\mathrm{D}$ & $A S \times D$ \\
\hline \multicolumn{11}{|l|}{ Digestibility coefficients } \\
\hline Dry matter & $0.731^{b}$ & $0.649^{a}$ & $0.644^{\mathrm{a}}$ & $0.729^{b}$ & $0.620^{a}$ & $0.658^{a}$ & 0.023 & & $* * *$ & * \\
\hline Organic matter & $0.761^{b}$ & $0.668^{a}$ & $0.670^{a}$ & $0.755^{b}$ & $0.643^{a}$ & $0.698^{b}$ & 0.033 & & $* * *$ & ** \\
\hline Crude protein & $0.805^{b}$ & $0.737^{\mathrm{a}}$ & $0.746^{\mathrm{a}}$ & $0.810^{c}$ & $0.675^{\mathrm{a}}$ & $0.757^{b}$ & 0.043 & * & $* * *$ & $* * *$ \\
\hline Neutral-detergent fibre & $0.643^{b}$ & $0.471^{a}$ & $0.507^{a}$ & $0.641^{c}$ & $0.430^{a}$ & $0.514^{b}$ & 0.037 & & $* * *$ & \\
\hline Acid-detergent fibre & $0.591^{c}$ & $0.332^{a}$ & $0.493^{b}$ & $0.589^{c}$ & $0.272^{a}$ & $0.374^{b}$ & 0.030 & $* *$ & $* * *$ & \\
\hline
\end{tabular}

a,b,c Within a row and animal species, means without a common superscript letter differ $(P<0.05)$.

${ }^{\dagger} \mathrm{AH}=$ alfalfa hay, $\mathrm{AHCO}=$ alfalfa hay and pellets (TSOC plus barley plus mineral-vitamin mixture), and AHCOP $=$ AHCO plus PEG.

${ }^{\ddagger} \mathrm{AS}=$ animal species effect, $\mathrm{D}=$ diet effect. 
Table 3 Daily nitrogen intake, faecal and urinary losses, nitrogen $(N)$ retention, total absorbable amino acids and percentage of requirements met in goats and wethers fed the experimental diets

\begin{tabular}{|c|c|c|c|c|c|c|c|c|c|c|}
\hline \multirow[b]{3}{*}{ Experimental $\operatorname{diet}^{\dagger}$} & \multicolumn{6}{|c|}{ Animal species } & \multirow[b]{3}{*}{ s.e.d. } & & & \\
\hline & \multicolumn{3}{|c|}{ Goats } & \multicolumn{3}{|c|}{ Wethers } & & \multicolumn{3}{|c|}{ Significance $^{\ddagger}$} \\
\hline & $\mathrm{AH}$ & $\mathrm{AHCO}$ & AHCOP & $\mathrm{AH}$ & $\mathrm{AHCO}$ & $\overline{A H C O P}$ & & AS & D & $A S \times D$ \\
\hline Daily $N$ intake $\left(\mathrm{g} / \mathrm{kg} \mathrm{M}^{0.75}\right)$ & 1.61 & 1.42 & 1.51 & $1.50^{\mathrm{b}}$ & $1.12^{\mathrm{a}}$ & $1.20^{\mathrm{a}}$ & 0.028 & ** & $* * *$ & * \\
\hline \multicolumn{11}{|l|}{ Percentage of $\mathrm{N}$ intake } \\
\hline Faecal & 0.20 & 0.27 & 0.24 & $0.18^{a}$ & $0.33^{\mathrm{b}}$ & $0.25^{\mathrm{a}}$ & 0.022 & & * & \\
\hline Urinary & $0.39^{b}$ & $0.46^{\mathrm{a}}$ & $0.59^{a}$ & $0.50^{\mathrm{a}}$ & $0.60^{\mathrm{b}}$ & $0.54^{\mathrm{ab}}$ & 0.032 & & * & \\
\hline
\end{tabular}

$a, b, c$ Within a row and animal species, means without a common superscript letter differ $(P<0.05)$.

${ }^{\dagger} \mathrm{AH}=$ alfalfa hay; $\mathrm{AHCO}=$ alfalfa hay and pellets (TSOC plus barley plus mineral-vitamin mixture), and AHCOP $=$ AHCO plus PEG.

${ }^{\ddagger} \mathrm{AS}=$ animal species effect, $\mathrm{D}=$ diet effect.

Treatment with PEG increased OMD of AHCO diet. Silanikove et al. (1994 and 1996) reported improvement in energy utilisation by goats and sheep fed tannin containing shrubs ( 5 to $20 \%$ DM) when supplying PEG to the animals. The different degree of improvement found in both cases may be due to, among other reasons, the different quality of the experimental diets, concentration and type of CT and method of PEG application (Getachew et al., 2001).

The PEG supply had a significant effect $(P<0.001)$ on CP digestibility only in wethers, which shows the superiority of goats to digest protein in the presence of CT. This could be explained either by a different rumen microbial population in goats and sheep as some works suggest (Brooker et al., 2000; Yáñez Ruiz et al., 2004) or by a more efficient overall $\mathrm{N}$ recycling in goats (Narjisse et al., 1995). Núñez-Hernández et al. (1991) reported a higher N digestibility in goats than in lambs when fed mountain mahogany (Cercocarpus montanus) leaves treated or untreated with PEG. Several nutritional studies comparing sheep and goats reported no differences in nutrient digestibility when moderate- or good-quality forages were fed (Isac et al., 1994; Molina Alcaide et al., 2000) but fibre digestibility of low-quality forages was greater in goats than in sheep (Doyle et al., 1984). In our work only ADF digestibility of AHCO and AHCOP diets differed between goats and wethers, being higher for goats, while values for $\mathrm{AH}$ diet remained similar for both animal species. In other studies involving low dietary $\mathrm{N}$ availability, goats also showed greater $\mathrm{N}$ digestibility than sheep (Bohra, 1980; Doyle et al., 1984).

\section{$N$ losses}

The different faecal $\mathrm{N}$ excretion response across the experimental diets between goats and wethers should be reflected in the amount of $\mathrm{N}$ retained. There is a lack of consistency regarding differences in $\mathrm{N}$ losses between these two species. Bohra (1980) found that goats had lower N losses than sheep when fed the same diet. Doyle et al. (1984) reported similar N losses when goats and sheep were fed subterranean clover hay or grass clover hay. However, with a ryegrass diet, goats lost less $\mathrm{N}$ than sheep did. Higher $(P<0.05)$ faecal $\mathrm{N}$ losses observed in wethers fed AHCO than AHCOP diet might indicate that some tanninprotein complexes are not fully hydrolysed in the gastrointestinal tract, hence reducing net protein absorption in the gut. Ben Salem et al. (1999) also reported a significant decrease in $\mathrm{N}$ loss in sheep after treating a diet based on Acacia cyanophylla with increasing amounts of PEG. Our data, regarding overall $\mathrm{N}$ losses, confirm the superiority of goats over sheep in challenging nutritional situations such as CT-containing diets or low $\mathrm{N}$ intakes as it has been previously pointed out by Silanikove (2000).

The increased urinary losses in animals fed AHCO compared with those fed $\mathrm{AH}$ might be explained by the decrease in the protein quality of the diets, especially in amino acid content, hence increasing the inefficiency of its

Table 4 Creatinine concentration and alkaline phosphatase (ALP) activity in serum of goats and wethers fed the experimental diets

\begin{tabular}{|c|c|c|c|c|c|c|c|c|c|c|}
\hline \multirow[b]{3}{*}{ Experimental diet ${ }^{\dagger}$} & \multicolumn{6}{|c|}{ Animal species } & \multirow[b]{3}{*}{ s.e.d } & & & \\
\hline & \multicolumn{3}{|c|}{ Goats } & \multicolumn{3}{|c|}{ Wethers } & & \multicolumn{3}{|c|}{ Significance $^{\ddagger}$} \\
\hline & $\mathrm{AH}$ & AHCO & AHCOP & $\mathrm{AH}$ & $\mathrm{AHCO}$ & AHCOP & & AS & $\mathrm{D}$ & $A S \times D$ \\
\hline Creatinine $(\mathrm{mg} / \mathrm{dl})^{\S}$ & 1.07 & 0.89 & 0.93 & 1.19 & 1.03 & 0.97 & 0.01 & & & \\
\hline $\operatorname{ALP}(I U / I)$ & 93.6 & 83.8 & 88.0 & $167^{\mathrm{a}}$ & $235^{b}$ & $238^{\mathrm{b}}$ & 68.7 & $* *$ & * & ** \\
\hline
\end{tabular}


use (Rotz, 2004). Indeed the amino acid nitrogen content and profile of the by-product has been reported to be very poor (Martín García et al., 2003). The lack of significant effect of PEG on urinary $\mathrm{N}$ losses suggests the absence of post absorptive effect of $\mathrm{CT}$ in both animal species.

\section{Liver and kidney function}

Previous works carried out with quebracho tannins reported the lack of toxicity (Frutos et al., 2000) at concentrations equivalent to those used in the present work. However, different results might be expected for tannins depending upon its chemical structure (Min et al., 2003) and, there is no information on TSOC tannins. The absorption of unmodified CT molecules is believed to be unlikely, due to their large size (Mueller-Harvey and McAllan, 1992). However, a possible intestinal damage could lead to absorption of CT and consequent systemic toxic effects (McLeod, 1974).

Damage to the kidneys would most likely lead to renal failure and to changes in serum creatinine (Zhu et al., 1995). The lack of effect on the creatinine serum concentrations above the normal physiological values after including TSOC in the diet and treating with PEG suggests that damage to the kidney did not occur to the experimental animals. This agrees with previous data (Yáñez Ruiz et al., 2004) that showed similar urinary creatinine excretion in goats and wethers fed the same diets.

Some authors have also considered a potential hepatic damage as a consequence of tannins absorption (Silanikove et al., 1996). The ALP levels are used to detect bile obstruction, i.e. a mild and progressive damage to the liver (Silanikove and Tiomkin, 1992). Garg et al. (1984) used a similar approach to demonstrate that feeding growing cattle with Shorea robusta did not induce systemic toxicity. However, changes in these parameters were found when tannin-related hepatoxicity occurred (Zhu et al., 1995). The ALP activity levels in the serum of animals were within the physiological range although affected by PEG treatment, suggesting that no damage to the liver occurred (Merck Veterinary Manual, 2006). A longer-term study of the effect of feeding similar diets on serum metabolites might be worthy.

\section{Conclusion}

Condensed tannins from two-stage olive cake had different effects on nitrogen losses and nutrient digestibility in wethers and goats. In wethers, $\mathrm{N}$ digestion was affected as a result of complexation between tannins and proteins, while no effect was found in goats. Our results report different digestive response in sheep and goats fed diets containing condensed tannins and show that at the concentration provided in the experimental diets, condensed tannins from TSOC are not toxic for both animal species. However, the impact of the byproduct on the digestibility, even in goats, make questionable the suitability of its use in practical conditions.

\section{Acknowledgements}

This work was funded by Junta de Andalucía (Project CA001-003).

\section{References}

Alburquerque JA, Gonzalez J, García D and Cegarra J 2004. Agrochemical characterisation of "alperujo", a solid by-product of the two-phase centrifugation method for olive oil extraction. Bioresources Technology 91, 195-200.

Ankom 2000. Procedures for fiber and in vitro analysis. Available:http://www. ankom.com. Accessed 14 December, 2000.

Association of Official Analytical Chemists 1984. Official methods of analysis, 14th edition. AOAC, Washington, DC.

Ben Salem H, Nefazaoui A, Ben Salem L and Tisserand JL 1999. Intake, digestibility, urinary excretion of purine derivatives and growth by sheep given fresh, air-dried or polyethylene glycol-treated foliage of Acacia cyanophylla Lindl. Animal Feed Science and Technology 78, 297-311.

Ben Salem H, Nefzaoui A, Ben Salem L and Tisserand JL 2000. Deactivation of condensed tannins in Acacia cyanophylla Lindl. foliage by polyethylene glycol in feed blocks. Effect on feed intake, diet digestibility, nitrogen balance, microbial synthesis and growth by sheep. Livestock Production Science 64, 51-60.

Bohra HC 1980. Nutrient utilization of Prosopis cineria (Khejri) leaves by desert sheep and goats. Annales Arid Zone. 19, 73.

Brooker JD, O'Donovan LA, Skene I and Sellick G 2000. Mechanisms of tannin resistance and detoxification in the rumen. In Tannins in livestock and human nutrition (ed. JD Brooker), Proceedings no. 92, pp. 117-122. ACIAR, Australia.

Bryant JP, Provenza FD, Pastor J, Reichardt PB, Clausen TP and Du Toit JT 1991. Interactions between woody plants and browsing mammals mediated by secondary metabolites. Annual Review of Ecology and Systematics 22, 431-446.

Doyle PT, Egan JK and Thalen AJ 1984. Intake, digestion and nitrogen and sulfur retention in Angora goats and Merino sheep fed herbage diets. Australian Journal of Experimental Animal Science 24, 165-169.

Frutos $\mathrm{P}$, Hervás G, Giraldez FJ, Fernández M and Mantecón AR 2000. Digestive utilization of quebracho-treated soya bean meal in sheep. Journal of Agricultural Science, Cambridge 134, 101-108.

Garg AK, Agrawal DK and Nath K 1984. Effect of sal (Shorea robusta) seed meal tannins on serum enzymes, nutrient utilization and growth in growing calves. Agricultural Wastes 11, 307-317.

Getachew G, Makkar HPS and Becker K 2001. Method of polyethylene glycol application to tanning-containing browses to improve microbial fermentation and efficiency of microbial protein synthesis from tannin-containing browses. Animal Feed Science and Technology 92, 51-57.

Hervás G, Pérez V, Giradlez FJ, Mantecón AR, Almar MM and Frutos P 2003. Intoxication of sheep with quebracho tannin extract. Journal of Comparative Pathology 129, 44-54.

Isac MD, García MA, Aguilera JF and Molina Alcaide E 1994. A comparative study of nutrient digestibility, kinetics of digestion and passage and rumen fermentation pattern in goats and sheep offered medium quality forages at the maintenance level of feeding. Archives of Animal Nutrition 46, 37-50.

Kumar R and Singh M 1984. Tannins: their adverse role in ruminant nutrition. Journal of Food Agriculture and Food Chemistry 32, 447-453.

Landau S, Perevolotsky A, Bonfil D, Barkai D and Silanikove N 2000. Utilization of low quality resources by small ruminants in Mediterranean agropastoral system: the case of browse and aftermath cereal stubble. Livestock Production Science 64, 39-50.

Martín García Al, Moumen A, Yáñez Ruiz DR and Molina Alcaide E 2003. Chemical composition and nutrients availability for goats and sheep of two-stage olive cake and olive leaves. Animal Feed Science and Technology 107, 61-74.

McLeod MN 1974. Plant tannins: their role in forage quality. Nutrition Abstracts and Reviews 44, 803-812.

Merck Veterinary Manual 2006. Available http://www.merckvetmanual.com Accessed 24 August, 2006.

Min BR, Barry TN, Attwood GT and McNabb WC 2003. The effect of condensed tannins on the nutrition and health of ruminants fed fresh temperate forages: a review. Animal Feed Science and Technology 106, 3-19.

Molina Alcaide E, Martín García Al and Aguilera JF 2000. A comparative study of nutrient digestibility, kinetics of degradation and passage and rumen fermentation pattern in goats and sheep offered good-quality diets. Livestock Production Science 64, 215-223.

Molina Alcaide E, Yáñez Ruiz D, Moumen A and Martín García I 2003. Chemical composition and nitrogen availability of some olive by-products. Small Ruminant Research 49, 329-336. 
Mueller-Harvey I and McAllan AB 1992. Tannin: Their biochemistry and nutritional properties. In Advances in plant cell biochemistry and biotechnology, Vol. 1 (ed. IM Morrison), pp. 151-217. JAI Press Ltd. London.

Narjisse H, Elhonsali MA and Olsen JD 1995. Effects of oak (Quercus ilex) tannins on digestion and nitrogen balance in sheep and goats. Small Ruminant Research 18, 201-206.

Nefzaoui A 1985. Valorisation des residus lignocellulosiques dans I'alimentation des ruminants par les traitements aux alkalis. Application aux grignons d'olive. PhD thesis, Universite Catholique de Louvain-la-Nueve.

Núñez-Hernandez G, Wallace JD, Holechek JL, Galyean ML and Cardenas M 1991. Condensed tannins and nutrient utilization by lambs and goats fed low quality diets. Journal of Animal Science 69, 1167-1177.

Pérez Maldonado RA and Norton BW 1996. Digestion of ${ }^{14} \mathrm{C}$-labelled condensed tannins from Desmodium intortum in sheep and goats. British Journal of Nutrition 76, 501-513.

Priolo A, Waghorn GC, Lanza M, Biondi L and Pennisi P 2000. Polyethylene glycol as a means for reducing the impact of condensed tannins in carob pulp: Effects on lamb growth, performance and meat quality. Journal of Animal Science 78, 810-816.

Ramos Cormenzana A, Juárez Jiménez B and García Pareja MP 1996. Antimicrobial activity of olive mill waste-waters (Alpechín) and biotransformed olive oil mill waste water. International Biodeterioration and Biodegradation 38, 283-290.

Reed JD 1995. Nutritional toxicology of tannins and related polyphenols in forage legumes. Journal of Animal Science 73, 1516-1528.

Reed JD 1986. Relationships among phenolics, insoluble proanthocyanidins and fiber in East African browse species. Journal of Range Management 39, 5-7.
Rotz CA 2004. Management to reduce nitrogen losses in animal production. Journal of Animal Science 82, E119-E137.

Silanikove N 2000. The physiological basis of adaptation in goats to harsh environments. Small Ruminant Research 35, 181-193.

Silanikove N, Gilboa N, Nir I, Perevolotsky A and Nitsan Z 1996. Effect of a daily supplementation of polyethylene glycol on intake and digestion of tannin-containing leaves (Quercus calliprinos, Pistacia lentiscus and Ceratonia siliqua) by goats. Journal of Agriculture and Food Chemistry 44, 199-205.

Silanikove N, Nitsan Z and Perevolotsky A 1994. Effect of a daily supplementation of polyethylene glycol on intake and digestion of tannin-containing leaves (Ceratonia siliqua) by sheep. Journal of Agriculture and Food Chemistry 42, 2844-2847.

Silanikove N and Tiomkin D 1992. Toxicity induced by poultry litter consumption: effect on parameters reflecting liver function in beef cows. Animal Production 54, 203-209.

Statistical Analysis Systems Institute 1985. SAS user's guide: statistics. SAS Institute Inc., Cary, NC.

Van Soest PJ and Masson VC 1991. The influence of the Maillard reaction upon the nutritive value of fibrous feeds. Animal Feed Science and Technology 32, 45-53.

Yáñez Ruiz DR, Moumen A, Martín García Al and Molina Alcaide E 2004. Ruminal fermentation and degradation patterns, protozoa population and urinary purine derivative excretion in goats and wethers fed diets based on two-stage olive cake: effect of PEG supply. Journal of Animal Science 82, 2023-2032.

Zhu J and Flippish LJ 1995. Acute intra-abomasal toxicity of tannic acid in sheep. Veterinary and Human Toxicology 37, 50-54. 